\title{
A NOVEL APPROACH TO EDUCATION FOR ENVIRONMENTAL SUSTAINABILITY
}

\author{
Parama Majumdar, Mousumi Bhowal, Deepika Sarda \\ Department of Botany, Hislop College, Nagpur, 440001, India \\ Corresponding author* mbhowal16@gmail.com
}

\begin{abstract}
:
Sustainability is defined as the emphasis laid on managing the existing capacity of Earth so as to uphold life in future. The Rio de Janeiro Earth Summit or the Earth Summit defined the concept of sustainability in the year 1992. This summit also laid the terms of sustainability through planning, negotiations and most importantly, through education. Education for Sustainability is a didactic approach that aims to develop human resource, across schools and communities with the values and motivation to take action for sustainability, within their community and therefore, also at a global scale. This paper discusses one such model that builds awareness and knowledge on sustainability issues by developing appreciation for nature among students. The basis of this extension model is engendering a process of critical thinking in the students through participatory learning as they work to organise a flower show which is the culmination of a yearlong upkeep while combating the changing tempers of the environment. The process encompasses several viable environmental solutions and the implementation of this model is an attempt to drive the cause of environment education through shared learning and to engage the society in a dialogue
\end{abstract}

Key words: - Earth Summit, sustainability, participatory learning, extension model

\section{INTRODUCTION:}

The 1992 United Nations Conference on Environment and Development, also called the Earth Summit, at Rio de Janeiro was unprecedented, both in terms of participation as well as the mandates set by it. It laid the foundation of the term 'sustainability' and at the same time proposed the term 'eco-efficiency' for the societal transformations. It also highlighted the importance of negotiations and education in the partner countries to attain the goal of sustainability United Nations (1997), further underlined the Sustainable Development Goals and the role of educating the children and youth to promote inclusive development and environmental protection United Nations (2012).
According to UNESCO, "Education for Sustainable Development empowers learners to take informed decisions and responsible actions for environmental integrity, economic viability and a just society, for present and future generations, while respecting cultural diversity." It also recognizes, designing the learning content, remodeling pedagogy and empowering learners of all ages, as 3 major areas of work to accomplish this objective UNESCO, (2018).

At the Department of Botany, Hislop College, a steady extension activity of floriculture and organization of "Flower Show", has been used to realize the learning outcome of awareness for environmental sustainability. This model is based on components of transformative, 
experiential, and collaborative learning, promoted by student teamwork Cranton (1996).

\section{MATERIAL \& METHODS:}

Floriculture: a pedagogic tool: Hislop College has been successfully exhibiting a wide range of healthy flowering plants under one roof for the last 15 years. This involves an in-house production of about 20000 plants cultivated entirely by the Department of Botany under its extension activity of Floriculture. The plants grown have a majority of Chrysanthemum which is an important and demanding horticultural crop, native to Asia. It is a shortday plant which is extremely sensitive to temperature during different phases of growth.

The approach used for cultivation is absolutely organic and does not involve any hormonal treatment or the use of chemical fertilizers. It involves yearlong participation of students and meticulous maintenance. This pursuit is a structured process of co-operative learning Moore, (2005) and Cranton (1996) where the students work together on the task, share information, and encourage and support each other under the guidance of an educator who directs and monitors the ultimate outcome of the experience. This training on sustainability comes from an amalgamation of various sections of the process which include multiplication of the crop and a set of allied activities that include nutritional upkeep, disease control, vermicomposting as well as begetting the appreciation for nature in the society.

Multiplication of the Crop: Chrysanthemum is a member of the family Asteraceae. Species of this plant are wildly cultivated all over the world and are commonly called Mums. They are cultivated as ornamentals and are boom for the floral industry. The cultivars which are commercially in demand include pompoms, buttons, daisy, large heads and spiders. Cuttings of chrysanthemums are taken out with the onset of monsoon from the plants that are already established in the college as mother plants. It is an inexpensive method to increase the number of plants.

The cuttings of about 2 to 3 inches are taken out with a sharp knife from the end of the mother plant shoot, which are around 3 to 5 inches tall. The leaves from the bottom of the shoot are removed leaving behind a pair of leaves at the top. The cut ends are put in sterilized moist beds for the purpose of rooting. The cuttings generally root in 3 to 4 weeks. The cuttings are then removed and potted into small pots containing fresh potting soil with a mixture of vermicompost, which has been fortified with a biopesticides. The apical buds of the small plants are pinched off to encourage branching. This process is continued till the month of September. This will eventually produce full, mound-shaped plant. The process of multiplication is simultaneously followed by manuring and disease management. Thrust is on organic manuring using feeding of liquid manures which are environment friendly and completely biodegradable. The months of October and November are dedicated to maintenance and development till the final bloom in the month of December.

Nourishment \& Crop Management: Enduring soil quality is one of the key factors in regard to environmental sustainability. Use of chemical fertilizers, pesticides, weedicides etc. for prolong periods, deplete the soil quality and also pollute water through surface runoffs. Practices of sustainability must therefore involve developing farming systems which improve water use efficiency and minimize risks of soil and water pollution, contamination and eutrophication. With this as the guiding 
principle the basic nourishment to the floriculture unit is provided through organic manuring techniques. Organic waste and litter generated in the campus is collected and treated in the vermicompost pits, resulting in stable nontoxic material manure which not only has a high nutrient value but is also a soil conditioner for plants.

The learners understand and maintain the population of Eudrilus eugeniae used as a bio agent for the conversion of organic wastes. The life cycle of this earthworm, nuances of composting and mode of application of the manure is a part of the module of instruction to the students.

Disease Control: Sustainable disease management tenders an environment friendly alternative for controlling plant diseases. The prevalence and incidence of Fusarium wilt and leaf blight disease is one of the major causes of poor crop quality in Chrysanthemum. The pathogens associated with wilt disease and leaf blight disease have been isolated and identified as Fusarium oxysporum and Alternaria alternate. Chemical pesticides and fungicides have been widely used to control plant diseases but they abuse the natural soil composition and lead to development of resistant pathogens, posing further threat Tahía Benitez (2004) .Ironically, greater specificity of a chemical against a pest organism also implies a greater chance of resistance development through genetic shifts in the population. Broad spectrum fungicides also produce undesirable consequences by affecting non-target organisms. EC (1992).

Biological control of soil borne plant pathogens by the addition of antagonistic microorganisms to the soil is a competent nonchemical method for plant disease control and is a step towards sustainable agriculture. The potential of
Trichoderma $\mathrm{sp}$. for this purpose has been established since early 20th century Y. Elad, (1980). Trichoderma species are free-living soil fungi that occur in nearly all the soils and other natural habitats. The use of microbial fungicides as one of the major components of integrated pest management is gaining acceptance, as these are generally specific, apparently harmless to the beneficial insects, animals, and human beings with no residue problems and environmental hazards. Understanding the potential of this, the students are trained on introducing Trichoderma cultures to the vermicompost, thus enhancing and enriching the organic formulation. This fortification is done by addition of spores of Trichoderma to the compost in a standardized amount. The mass production of the mycelium and spores is undertaken by students and its addition to the vermicompost fortifies it for pathogen control.

Sensitization of Society: The entire process of raising a crop culminating in the flower show is a major platform showcasing the benefits of floriculture through the majestic blooms. The show is covered by all the major newspapers of the city with an official press release from the department that mentions all the major steps taken throughout the year to present this show.

As an attempt to engender sensitivity for nature among young minds, school students are taken around the unit, throughout the year where they can understand the different stages of bringing up the plants. Further, the composition of the show includes a sit-anddraw competition for school students between the age range of 11 to 14 years.

\section{RESULT AND DISCUSSION:}

Learning outcomes: The learning module is entirely designed to empower learners with a life sustaining skill while also developing a 
critical and systemic thinking. Students are involved throughout the period of development of the crop. They acquire training on propagation techniques and a hands-on experience of the practical difficulties of crop maintenance, thereby developing the cognitive skills to analyze the cause and effect relationship and also develop collaborative problem-solving skills Jauharoti Alfin (2019). The modules also instill a sense responsibility for present and future generations, which is key to sustainability Meredith Root-Bernstein, (2014), UNESCO (2018), Moore (2005). The perceptive skills with respect to the mandate of sustainability are discussed in Table 1.

This model also aims at creating "Green Jobs" UNESCO (2018) by imparting an entrepreneurial skill. In the practical learning environment of raising and maintaining a crop, students acquire the core competencies of

- Floriculture; which involves propagation and sustenance of the crop.

○ Vermicomposting; involving experiential learning of organic waste management.

- Allied techniques; that include manuring, Trichoderma application etc.

These techniques have now been amalgamated with the mainstream wherein students are taking up various aspects of this unit for further research activities. The job giving potential of this model has also been identified by UGC under its Career Oriented Course as well as by the RTM Nagpur University as a Certificate course in Allied Agricultural Skills.

\section{CONCLUSION}

With the implementation of this model we have tried to drive the cause of environment education through shared learning, not just for the young minds that have been a part of the fold but also for schools and community at large. During the course of developing this module, we have also picked up the cause of sensitization and tried to engage the society in a dialogue. We consider Nagpur to be our abode and over the years we have managed to pin this system on to the cultural map of the city, thus positioning it as a meeting ground of sorts for both current and prospective environment appreciators.

\section{REFERENCES:}

Alfin, J., \& Fuad, A. H. (2019). Development of Group Science Learning (GSL) Model to Improve the Skills of Collaborative Problem Solving, Science Process, and SelfConfidence of Primary Schools Teacher Candidates. International Journal of Instruction, 12(1), 147164.

Cranton P., (1996) Types of group learning. New Directions for Adult \& Continuing Education 71 : 25-32

EC, T. (1992 ). Selective Elimination of Soil Borne Pathogens and Enhancement of Antagonists by Steaming and Sublethal Fumigation and Soil Solarization. In P. G. Tjamos EC, Biological control of plant diseases. Progress and challenges for the future. New York: Plenum Press

Education for Sustainability

Retrieved from www.unesco.org: https://en.unesco.org/themes/edu cation-sustainabledevelopment/what-is-esd. 
Jauharoti Alfin, A. Z. (2019). Development of Group Science Learning (GSL) Model to Improve the Skills of Collaborative Problem Solving, Science Process, and SelfConfidence of Primary Schools Teacher Candidates. International Journal of Instruction, 12(1): 147164.

Meredith Root-Bernstein, M. R.-B.-B. (2014). Tools for thinking applied to nature: an inclusive pedagogical framework for environmental education. Fauna \& Flora International, Oryx, 584-592.

Moore J., (2005) Is Higher Education Ready for Transformative Learning? A Question Explored in the Study of Sustainability. Journal of
Transformative Education 3 (1): 7691.

Tahía Benítez A. M., (2004). Biocontrol mechanisms of Trichoderma strains. International Microbiology, 249-260.

United Nations. (1997, May 23). Rio 1992. Retrieved January 2019, from www.un.org:

http://www.un.org/geninfo/bp/env iro.html

United Nations. (2012). Rio 2012. Retrieved from www.un.org:https:// sustainabledev elopment.un.org/rio20

Y. Elad, I. C. (1980). Trichoderma harzianum: A Biocontrol Agent Effective Against. The American Phytopathological Societ, 119-121. 
Table 1: Details of the learning outcomes in form of the cognitive skills learnt and their implementation

\begin{tabular}{|c|c|c|}
\hline $\begin{array}{l}\text { COGNITIVE } \\
\text { SKILL }\end{array}$ & DESCRIPTION & IMPLEMENTATION \\
\hline Observation & $\begin{array}{l}\text { Accurate } \\
\text { perceptions } \\
\text { and } \\
\text { symptomatic } \\
\text { identifications }\end{array}$ & $\begin{array}{l}\text { Identification of various factors affecting } \\
\text { plant growth and understanding the } \\
\text { intricate role played by each component } \\
\text { of nature; both biotic and abiotic. } \\
\text { Generating data. }\end{array}$ \\
\hline Analysis & $\begin{array}{l}\text { Examination of } \\
\text { situation and } \\
\text { framing the } \\
\text { problem } \\
\text { statement }\end{array}$ & $\begin{array}{l}\text { Examination of the multidimensional } \\
\text { role of components of the ecosystem and } \\
\text { its bearing in sustainable management } \\
\text { of the available resources. }\end{array}$ \\
\hline Extrapolation & $\begin{array}{l}\text { Recognizing } \\
\text { the pattern } \\
\text { and } \\
\text { translating it } \\
\text { to possible } \\
\text { consequences }\end{array}$ & $\begin{array}{l}\text { Discerning the dynamic system and \& } \\
\text { developing guidelines based on previous } \\
\text { observations. }\end{array}$ \\
\hline $\begin{array}{l}\text { Independent } \\
\text { Thinking }\end{array}$ & $\begin{array}{l}\text { Developing } \\
\text { plan of action } \\
\text { to suit the } \\
\text { situation }\end{array}$ & $\begin{array}{l}\text { Implementation of acquired know-how to } \\
\text { develop ecologically sustainable models }\end{array}$ \\
\hline $\begin{array}{l}\text { Collaborative } \\
\text { Problem } \\
\text { Solving }\end{array}$ & $\begin{array}{l}\text { Reaching to } \\
\text { the solution by } \\
\text { sharing } \\
\text { individual } \\
\text { learnings }\end{array}$ & $\begin{array}{l}\text { Developing models for negotiation, } \\
\text { mediation and conflict resolution } \\
\text { working with team members and stake } \\
\text { holders. }\end{array}$ \\
\hline Synthesis & $\begin{array}{l}\text { Devising a } \\
\text { long-term plan }\end{array}$ & $\begin{array}{l}\text { Being aware of multiple parameters } \\
\text { simultaneously and studying them in a } \\
\text { restoration context to developing a long- } \\
\text { term plan. }\end{array}$ \\
\hline
\end{tabular}

